\title{
Uyarlama Sinema Filmleri Üzerine Bir Sorgulama: Sinema Seyircilerinin Okuma Pratikleri
}

\author{
Reyhan Yildiz Kayadevir*
}

\section{Özet}

Edebiyat çoğu zaman bilhassa konu bakımından sinemayı desteklese de, zaman zaman edebiyat ve sinema ilişkisi iç içe geçmekte ve yaşanan kültürel değişimin de etkisi ile sinemayı, edebiyatın neredeyse hatırlatıcısı konumuna getirmektedir. Öyle ki, günümüz edebiyattan uyarlama filmleri, çoğu izleyicinin edebî eser olarak bilmediği veya bildiği, fakat zaman yaratıp okumadı̆̆ı eserlerden oluşmaktadır. Bu uyarlama filmlerin etkisi edebî eserin önüne geçtiğinde, izleyici filmin kitabı ile karşılaştığında kitabı filmden dolayı bir merak ile satın almaktadır. Bakıldığında edeb̂̂ eserin bilinirlik düzeyi filmin yanında sönümlenirken, eskinin okuma pratikleri de yerini yeni okuma pratiklerine bırakmaktadır.

Sinema ve edebiyat ilişkisi bağlamında değerlendirildiğinde, bu çalı̧̧mada sinema seyircisinin okuma pratikleri ele alınacak, sinema seyircileri ile yapılacak görüşmeler için yarı yapılandırılmış derinlemesine mülakat tekniği ile alımlamalarn incelenecektir. İleyici, sinemada izlediği filminedebiyateseriolduğunun farkında mı? Farkında ise, bu eseri daha önce okumuş mu? Okuduğu eseri bir de sinemada görmek için mi gelmiş, yoksa eseri çok duymuş, fakat okumak yerine sinemada izlemeyi mi tercih etmiş? Bu sorular ışığında izleyicilerde edebiyat ve sinema ayırdı olup olmadı̆̆ı, farkındalık seviyeleri, bilinç düzeyleri hakkında bilgi edinilebilir. Ayn zamanda görüşmecilerden alınan cevaplar günümüz sinemasının gölgesinde seyreden edebiyat açısından değerlendirildiğinde, izler kitlenin okuma pratiklerini ortaya koymak açısından önemlidir.

Anahtar Kelimeler: Uyarlama Sinema Filmleri, Alımlama, Okuma Pratikleri.

ORCID ID : 0000-0003-2332-8706

E-mail : reckcesc@gmail.com

DOI: 10.31122/sinefilozofi.508817

Geliş Tarihi - Recieved: 06.01.2019

Kabul Tarihi - Accepted: 10.04.2019 


\title{
Reading Practises of Cinema Audience: An Analysis of the Film Adaptations
}

\author{
Reyhan Yildiz Kayadevir*
}

\begin{abstract}
Although literature often feeds into cinema in terms of subject matter, at times the relationship between literature and cinema is closely intertwined to such an extent that cinema almost serves as a reminder of the literary work. Thus, most people first encounter the story through adaptations today but not necessarily through original literary work. Some members of audience would not know the work at all while others do but are unable to allocate time to read. When these adaptation films have a greater effect, they would feed the curiosity and desire of the audience in accessing their book versions. While the level of recognition (familiarity) of the literary work is fading beside the film, the reading practices of the old are also replaced by the new.

This study will examine the reading practices of the cinema audience and use semi-structured in depth interview techniques with their members in order to discuss the audience's receptiveness. Is the audience aware that the film is based on a literary work? If they are, have they read the work before? Has the reading made them want to see the work in the cinema, or instead of reading at all, have they preferred to see it on screen? In the light of these questions, it is possible to obtain information about whether there is a distinction between literature and cinema for the audience, but also to examine the consciousness and awareness levels. The outcomes would also serve to reveal the reading practises of the audience once the answers are evaluated in terms of the literature which is overshadowed by today's cinema.
\end{abstract}

Keywords: Adaptation Cinema Films, Reception, Reading Practices.

ORCID ID : 0000-0003-2332-8706

E-mail : reckcesc@gmail.com

DOI: 10.31122/ sinefilozofi.508817

Recieved - Geliş Tarihi: 06.01.2019

Accepted - Kabul Tarihi: 10.04.2019 


\section{Giriş}

Edebiyat, sinema sanatı var olduğundan bu yana hemen hemen her dönemde sinemaya eşlik etmiş, edebiyat eserlerinin sinemaya konu oluşuyla başlayan bu birliktelik günümüze kadar da süregelmiştir. Edebiyat ve sinemanın birlikteliği çok konuşulan, oldukça eleştirel bir birliktelik olsa da, bu iki alan birbirini desteklemeye devam etmiştir. Sinema ve edebiyat birlikteliğinde, sinemanın edebiyat eserlerini konu edinirken, edebiyat eserinin özgünlüğünü gözetmemesi durumu kuşkusuz en çok tartışılan konuların başında gelmektedir. Burada ise, sinemaya uyarlanan eserlerde özgünlük tartışması sürekli gündeme gelirken, uyarlama filmlerin ne denli aslını yansıtıp yansıtmadığından ziyade, izler kitle ve okurun uyarlama filmler hususunda öncelikleri, farkındalıkları ve değerlendirmeleri çalışmanın ana hatlarını oluşturmaktadır.

Çalışma, edebiyat ve sinema ilişkisi bağlamında “21. yüzyılda sinema, edebiyatın hatırlatıcısı konumunda mı?" sorusundan hareketle; edebiyat-hayal gücü ve uyarlama filmlerde metin-senaryo ilişkisini sinema ve edebiyat birlikteliğinde okur ve izler kitle görüşleri üzerinden değerlendirmektedir. Çalışmanın ilk varsayımı, 21. yüzyılda sinemanın izleyiciye görsel efektler ve tekniklerle daha kısa sürede, daha fazla tüketim imkânı sunduğundan dolayı hız çağına en uygun araç olduğu yönündedir. Bu durumda bu varsayım etrafında, edebiyat ve sinema ilişkisi iki yönlü değerlendirilebilir: Edebiyat sinemayı konu bakımından beslemektedir ve sinema da edebiyat eserini gündeme taşımaktadır. Sinema ve edebiyat birlikteliğindeki bu karşılıklı etkileşimden dolayı sinema ve edebiyat sık sık birlikte anılmaktadır. İki alan arasındaki tartışmaların odağını edebî eserin özgünlüğü oluştursa da, bu çalışmada, edebiyat ve sinema birlikteliğinde hangi tarafın diğerine üstünlüğü ve zayıflığından ziyade, iki tarafın da tercih edilmesinde izler ve okur kitle görüşleri bağlamında bir değerlendirme amaçlanmaktadır. Çalışma edebiyatın sinema karşısında değer kaybettiğini savunan görüşü dikkate alarak, izleyicilerin okuma pratiklerini gözlemlemek açısından önemlidir.

Sinema ve edebiyat birlikteliğinde okur ve izler kitle görüşlerini almak için yarı yapılandırılmış derinlemesine mülakat yöntemi kullanılmıştır. Bu görüşmelerden elde edilen veriler, çalışmanın birincil veri kaynaklarını oluşturmaktadır. Literatür taraması kapsamında incelenen; kitap, dergi, makale ve elektronik kaynaklar çalışmanın ikincil verilerini oluşturmaktadır. Yarı yapılandırılmış derinlemesine mülakat soruları hazırlanırken edebiyatı ayrı, sinemayı ayrı ele alan ve ardından iki alanı da sentezleyen sorular üzerinden çok yönlü bir sorgulama yapılmıştır. Sorular okur ve izler kitlenin uyarlama filmlere bakış açısını ortaya koyarken aynı zamanda her iki kitlenin de her iki alanla bağlantısı ve farkındalık seviyelerini de ölçümlemektedir. Görüşmecilerin sorulara verdiği cevaplar bağlaminda okuma pratiğinin izleme pratiği ile yer değiştirip değiştirmediği gözlemlenmeye çalışılmıştır.

Sinema ve edebiyat birlikteliğinde okur ve izler kitle görüşlerini değerlendirmek için seçilen görüşmeciler, kartopu örneklem yöntemi ile belirlenmiştir. Edebiyatla bağlantılı olarak okur kısmını temsil eden ve kitaplarla ilişkileri daha derin olan kütüphanecilerle başlayan görüşmeler, sinemayı temsilen, izler kitle kısmını oluşturan aynı zamanda popüler kültürü de temsil edeceği ön görülen öğrenciler ile eş zamanlı olarak devam etmiştir. Belirli bir sayıya ulaştıktan sonra cevaplar birbirini aynı şekilde takip etmeye başladığında, sonucun değişmeyeceği öngörüldüğünden görüşmeler sonlandırılmıştır. Çalışmanın örneklem evreni yirmi görüşmeci ile sınırlandırılmıştır. Bu görüşmeciler kütüphaneciler ve öğrencilerden oluşmaktadır. Çalışma, görüşmecilerin sinemada izleme pratikleri ile okuma pratiklerini sentezlerken, aynı zamanda bu pratiklerifarkındalık açısından sorgulayan bir saha çalışmasıdır. 


\section{Edebiyat ve Hayal Gücü İlişkisi}

Filmin kısa süreli tutsaklığıyla kıyaslandığında, edebiyat eseri filme oranla oldukça uzun bir yolculuk olarak tanımlanabilir. Edebî eserin her sayfasında ayrı bir dünyaya sürüklenirken, her satıra hayal gücü eşlik etmektedir. Kişinin hayal gücü ile eşlik ettiği satırlarda dilediğince gezinme ve düşünme özgürlüğü bulunduğundan dolayı yaratıcılık da aynı oranda gelişme göstermektedir. Esslin (2001:35) edebiyat ve sinema ilişkisini Shakespeare'in Hamlet'i ve Tolstoy'un Savaş ve Barış'1 üzerinden değerlendirmektedir. Bu kitapları okurken imajları zihnimizde dönüştürüyoruz; fakat izlerken bu süreç tersine dönmektedir. Çünkü izlerken yaratılan imgeleri görmekte ve duymaktayız; fakat okuma sürecine eşlik eden imgeleri hayal gücümüzde yaratmaktayız. Bu nedenle aynı kitabı okuyan birçok kişi zihninde farklı karakterler yaratabilmektedir. Fakat film söz konusu olduğunda zihinde yaratım süreci, filme aktarılanlarla sinırlanmaktadır.

Kitabın her bireyin zihninde farklı canlanan imgeleri sinemada birden çok faktöre bağlıdır. Çünkü sinema bir ekip çalışmasıdır; fakat edebiyat eseri bireysel bir üretimdir. Sinema maliyetli ve zaman kısıtı bulunan bir araç olmasına rağmen edebî eser bu konuda esnektir. Yazarın tasvir ettiği yerlerin sınırı tamamen okurun hayal gücüne bağlıdır (Kale, 2010:267). Her okur, farklı hayal ettiğinden dolayı, her biri kendi yolculuğunu yaşamaktadır. Edebî eserde zaman, mekân ve karakter sınırlaması olmadığından dolayı, hayal gücü bireyin hayal gücüyle paralel ilerlemektedir.

Currie (1995:164) sinemay1, hikâyeyi görsel şekilde sunan bir araç olarak tanımlamaktadır. Bu yolla hikâye, dilsel biçimlerden ayrılmaktadır. Dilsel ve görsel arasındaki farkı anlamaya çalışırken, "görselliğin ne gibi farklı bir deneyim olduğu?" sorusuyla karşılaşmaktayız. Çünkü izlediğimiz filmler okuduğumuz romanlardan da tiyatro oyunlarından da çok farklıdır.

Bu bağlamda değerlendirildiğinde, edebiyatın hayal gücü ile ilişkisi bireyin hayal etme yetisi ve yaratıcılık ile bağlantılıyken, film söz konusu olduğunda yönetmenden oyuncuya, mekân seçimine kadar birçok faktör ortaya çıkmaktadır. Okunan eserde karakterin zihinde yaratım süreci, büyük oranda bireyin hayal dünyası ile tamamlanırken, izlenen filmde karakterin imajı, güzel veya çirkin oluşu, ses tonu dahi bireyin hayal dünyasına müdahale olarak değerlendirilebilir. Öyle ki, kitapta sayfalarca betimlenen bir an, sinemada kullanılan efektler ile büyülenmiş bir ana dönüşebiliyor.

\section{Uyarlama Filmlerde Metin-Senaryo İlişkisi}

Uyarlama filmlerde konunun özgünlüğ̈̈̈nden ziyade filme ayrılan sürede en etkili anlatımı yapmak amaçlanmaktadır. Bu durumda edebî eser satır satır irdelenemeyeceğinden dolayı, anlatının en can alıcı noktalarından kesip biçilerek yeni bir form oluşturulmaktadır. Robert Stam (2014:21) sinemanın özgünlük meselesini edebiyat ile kıyaslamalı bir şekilde saygınlık sorunuyla birlikte ele almıştır. Stam'a göre edebiyatın sinemaya kıyasla daha saygın bir alan olarak görülmesi, edebiyatın bin yıllık bilgi birikimi ile sinemanın yüzyıllık üretiminin karşılaştırılmasının sonucudur. Öte yandan sinemanın aktarım kaynaklarının daha fazla olduğunu ve sinemanın edebiyata oranla daha güçlü ve değerli olduğunu savunmaktadır. Sinemanın edebiyat üzerindeki üstünlüğünü, edebiyatın sadece yazı ile aktardığını görsel efektler ve müzik ile destekleyerek verdiği yönünde örneklerle çoğaltabiliriz; fakat bütün bunlar sinemanın aktarım gücünün çeşitliliğini açıklamak dışında edebiyatın etkisini 
yadsımamıza yeterli değildir.

Sinema sözcügü cinematographie sözcüğünden kısaltılmıştır. Lumiere kardeşler kendi buldukları aygıta sinematograf adını vermiştir. Yunanca atos=devinim ile graphein=yazmak sözcüklerinden türemiştir. Yeni buluşun en önemli özelliği, yaşamı olduğu gibi yansıtabilmesidir (Özön, 2008:3). Sinematografinin getirdiği yenilik, insanların kökeni çok eski tarihlere uzanan, hareketli görüntüler elde edebilmek isteğinin gerçekleşmiş olmasından kaynaklanmaktadır. Beyaz perdede görülenler insanları heyecanlandırmış ve bu yeni deneyim ile seyirci görsel, canlı bir serüvene katılmıştır (Teksoy, 2005:116). Sinema teknolojisi geliştikçe yönetmenler ilham almak için edebiyata da başvurmuştur. Fakat herhangi bir romandaki uzun bir anlatıyı, görece kısa sürelerin, yani bir filmin içine sokmak zor olmuş, ardından daha büyük bütçeler ve Hollywood film stüdyolarının ortaya çıkması yapımcıları cesaretlenmiştir (Kemp, 2014:18-19).

Dmytryk ve Dmytryk (2007:19) film malzemesi olarak üç ana kaynaktan bahsetmektedir: Tiyatro oyunu, roman ve özgün senaryo. Film öykülerinin çoğu roman uyarlaması olmakla birlikte, ortalama bir roman bir filmden uzun olduğundan dolayı iyi bir seçim ve çokça kırpma gerektirmektedir. Filmin ana temasını özetleyen bölümler bir araya toplanırken bu bölümleri anlamlı kılacak bağlantılar da eklenmektedir. Ünal (2015:159) kurguyu bir eksiltme sanatı olarak tanımlamıştır. Bir filmin karakterlerinin hareketini bir bütün olarak vermesi imkânsızdır. Gerçek hayatta kırk beş dakika sürecek bir yemek sahnesi, film anlatısında iki dakikaya düşebilir ya da uçakla New York'dan İstanbul'a normalde on altı saat sürüyorken, filmde on altı dakika sürebilir. Bu filmsel anlatım yöntemine derişik zaman adı verilmektedir.

Sinema da edebiyat gibi bir anlatı çeşidi olmakla birlikte, sinemanın ilk ortaya çıkışından bu yana edebiyat eserini konu alışı dikkatleri çekmektedir. Bakıldığında sinema ve edebiyat birer anlatı çeşidi olsa da, ikisi de farklı anlatım tekniğini kullandığı için farklı yorumlamalara da açık olmaktadır. Sinemanın görsel anlatısı, edebiyatın yazınsal gücünden faydalanıyor olsa bile, aynı anlatı sinemanın görsel anlatısında bazen bambaşka bir şeye dönüşebilmektedir.

Bu durumda bir edebiyat uyarlamasında yazar, film ekibi ile iş birliği içerisinde olsa da, filmi izlediğinde genelde yazdığı eserden bağımsız bir iş ile karşılaşmaktadır. Neredeyse bu durum bütün uyarlama filmlerde yazar ile sinemacı arasındaki ana çatışmadır (Yüce, 2005:5) denilebilir. Bakıldığında sinema ve edebiyat ilişkisi daha ziyade sinemanın kendine özgü nitelikleri çerçevesinde gerçekleşmektedir. Diğer sanatlarda olduğu gibi, sinema edebiyattan yararlanırken kullandığı malzemenin içeriğini ya da biçimini değiştirmektedir (Uğurlu, 1992:140). Bu nedenle uyarlama filmler çoğu zaman edebî eserden farklı seyretmektedir.

Sinemanın edebiyat eserini konu alışını değerlendiren Kayaoğlu (2016:28), filmin edebiyatı örnek aldığını söylerken bunun nedenini teknik yetersizlikler (film şeritlerinin kısalığı, montaj ve çekim ayarı tekniklerinin gelişmemiş olması) ve yeterli senaryo bulunmayışı ile açıklamaktadır. Bu yönüyle edebiyat sinemaya hazır senaryo sağlamaktadır. Kırel (2014:118) de benzer bir bakış açısıyla sinema ve edebiyat birlikteliğinde asıl nedeni, sinemanın anlatacak öykülere ihtiyaç duymasına bağlamaktadır. Sinema eğlence aracı olarak izleyicilere öyküler anlatmakta, edebiyat da sinemaya bu öyküleri sağlamaktadır. Başka deyişle yazılı eserlerin çoğu, sinema için hazır malzeme olanağı sunmaktadır.

Nitekim sinemanın başlangıcından beri uyarlamalar, sinemanın temelini oluşturmaktadır. İlk filmler arasında edebî eserlerin uyarlamaları yer almaktadır (Cartmell, 
2012, s. 2). Sinema kendisini bir anlatı eğlencesi olarak görmeye başlar başlamaz, anlatı deposu olarak romanı kullanmaya başlamış ve bu süreç son doksan yıl boyunca azalsa da devamlılı̆̆ını da korumuştur (McFarlane, 1996:6). Akbayır (2014:7) sinemanın ortaya çıktığı zamanlarda konularını edebiyattan, oyun tarzını ise tiyatrodan aldığını söylemektedir. Dolayısıyla sinema dilinin gelişmesinde roman etkili olmuştur denebilir.

Öyleyse sinema uzun yıllar yazılı metnin gölgesinde yaşamıştır. Edebiyatın anlatı dili üzerine kurulu bir sinema dili, günümüzde hala geçerliliğini korumaktadır. Hemen hemen her filmde başı ve sonu olan olaylar dizisi anlatılmaktadır (Ertürk, 2008:42). Sinemayla birlikte dilde yaşanan hızlı değişimi anlatmak için verdiği örnekte Baydur (2004:142), televizyon öncesi cezasını çekmiş, on veya on beş yıl içerisinde geri dönmüş mahkûmların ilk zamanlarda filmleri takip etmekte çok zorlandıklarını anlatmaktadır. Film ve kitap kıyasında ise, okurun kitabı yarıda bırakıp dilediği işler ile ilgilendiği, dilediği zaman da kitaba geri döndüğü keyfi bir zaman dilimiyle, sinemanın aynı keyfiliği kabullenmeyeceğini ve iki saatlik bir pasiflik gerektirdiğini anlatmaktadır (Baydur, 2004:145).

Uyarlamaların belki de en bilinen örneklerinden Mary Shelley'nin Frankenstein kitabı sinemaya uyarlandığında, edebî eserin bilinirliğinden çok daha popüler bir figür yaratılmıştı. Seda Artar (2005:261)'in da belirttiği gibi bugün, Frankenstein denince akla doktor değil de, canavar gelmektedir. Oysa kitapta Frankenstein doktorun adı olduğu gibi, yaratık yeşil de değildir, fakat sinemanın görsel anlatısı kitabın önünde seyretmiştir.

\section{Edebiyat ve Sinema Birlikteliğinde Okur ve İzler Kitle Görüşleri}

\section{1. yüzyılda sinema ve edebiyat alışkanlıkları}

Kişiler seçtikleri filmleri daha çok ilgi alanlarına yönelik alanlardan seçerken, kitap okuma alışkanlığı film izlemeye oranla oldukça düşüktür. Filmleri iyi ya da kötü olarak değerlendirme kıstaslarının başında "filmin sıkıcı olmaması" gelmektedir. Görüşmeciler için "Hoşça vakitgeçirme" iyi film kıstasında önemlibiryere sahiptir. Bu açıdan değerlendirildiğinde hız çağına uygun bir araç olarak görsel anlatı, sinemayı görüşmecilerin gözünde daha cazip kılmaktadır. Görüşmeciler vizyon filmleri takip etmenin yanında, en uzun süreli olarak haftada bir film izlediklerini beyan etmektedir. Bu durumda görüşmecilerin düzenli sinema alışkanlıklarının olduğu söylenebilir. Edebiyat kısmıyla ilgili verilen cevaplarda ise, yine hemen hemen hepsi düzenli okudukları bir kitapları olduğunu söylese de her gün ya da haftada bir gün film izleme alışkanlıklarına bakıldığında kitap okuma alışkanlıklarının sinema kadar yoğun olmadığı söylenebilir. Düzenli bir okuma alışkanlığı olduğunu ve iyi bir okur olduğunu beyan eden kişilerin ise, sinema alışkanlığının diğerlerine oranla neredeyse yok denecek kadar az düzeyde olduğu görülmektedir. Film izlemek yerine kitap okumayı tercih ettiğini söyleyen bireylerin zamanlarını okumaktan yana kullandıkları görülmektedir. Bu bağlamda değerlendirildiğinde "zaman" kavramı ile karşı karşıya bir tercih söz konusu olduğu düşünülebilir. Boş vakit eylemi olarak: okumak veya izlemek.

Sinema açısından değerlendirildiğinde, izleyicinin farkında olmadığı uyarlama film hakkında söz söyleme yetisi yalnızca film üzerinde sınırlandı ğından, eseri ve filmi karşılaştırma yaparak değerlendirmesi de oldukça güçleşmektedir. Uyarlama bir filmi "başarılı bir uyarlama" olarak değil de, yalnızca iyi bir film olarak değerlendirebilmektedir. Başarılı veya başarısız ayırdı, iyi ve kötü kavramsallaştırması altında sığlaşmaktadır.

Görüşme için hazırlanan sorularda görüşmecilerin izledikleri filmi ve okudukları 
kitapları neye göre seçtikleri, farkındalık düzeyleri hakkında bilgi vermesi açısından önemlidir. Bu nedenle çalışmaya "iyi bir izleyici mi, iyi bir okur mu yoksa her ikisi de mi" olduklarını ortaya çıkaran sorular ile başlanmıştır.

\section{Sinema alıșkanlığınız ne düzeyde?}

Aklıma geldikçe evde film izlerim, sinemada vizyona giren filmleri takip ederim, sinemada ilgimi çeken film olursa giderim. (Erkek/41/Kütüphaneci/İzmir)

Sıkı bir takipçisi olmadığımı söyleyebilirim. Sinema ile ilişkim asgari düzeyde. Evde izlemek de yeni yeni alışkanlık edindim. Yakın zamana kadar neredeyse hiç film izlemezdim. Vizyona giren filmleri de nadiren izlerdim, ilgimi çekerse. Birçok kişiye göre herhalde çok az izliyorum. Birçok kişi film izlerken, ben kitap okuyordum mesela işyerinde vaktimiz olduğu zaman. Kitap okumak daha ilgimi çekiyordu ondan vakit ayırmak çok gerekli gelmiyordu. Bazı kitapların filmi olduğu zaman ilgimi çekerdi onun dışında çok ilgimi çekmiyor. (Erkek/29/Kütüphaneci/İstanbul)

Sinemada ilgimi çeken film olursa giderim. (Erkek/55/Kütüphaneci/Ankara) İstanbul)

Evde, haftada bir film izlerim. Vizyon filmlerini de takip ederim. (Kadın/29/Kütüphaneci /

Evde haftada bir film izler, vizyona giren filmleri takip ederim, kışın haftada bir sinemada film izlemeye çalışırım. (Erkek/43/Kütüphaneci/İstanbul)

Sinemada ilgimi çeken film olursa giderim. (Kadın/22 /Lisans Öğrencisi/Bartın)

Aklıma geldikçe evde film izlerim. (Erkek/23/Lisans Öğrencisi/İstanbul)

Aklıma geldikçe evde film izlerim ve sinemada ilgimi çeken film olursa giderim. (Erkek/27/ Yüksek Lisans Öğrencisi/İstanbul)

Sinema alışkanlığım iyi düzeyde, firsat buldukça sinemaya giderim ayrıca her akşam film izlemeye çalışırım. (Kadın/21/Lisans Öğrencisi/İstanbul)

Genellikle aklıma gelince canım sıkılınca film izlerim ama şu ana kadar baya çok film izlemişimdir. Bir de zaman aralıklarım vardır benim mesela bundan 3-4 sene önce daha çok film izliyordum şimdi o kadar izlemiyorum. Sıklıkla izlerim ama aklıma geldikçe. (Erkek/25/Lisans Öğrencisi/Çanakkale)

Her akşam olmasa da iki günde bir evde film izlerim, vizyona girecek olan film ilgimi çekiyorsa öncesinden takip ediyorum ve vizyona girdiğinde izliyorum. (Erkek/21/Lisans Öğrencisi/ İstanbul)

Evde haftada bir film izlerim. (Kadın/24/Lisans Öğrencisi/İstanbul)

Internette sürekli dizi film izliyorum. Sinemaya gitmiyorum internetten takip etmeyi seviyorum. (Kadın/29/Kütüphaneci/İstanbul)

Haftada sanırım yaklaşık 4-5 film izlerim. Vizyona giren filmleri takip etmeye çalışırım, ilgimi çeken film olursa giderim. (Kadın/30/Yüksek Lisans Öğrencisi/İstanbul)

Iyi bir sinema izleyicisiyim. Kimi zaman evde, festivallerde, çeşitli gösterimlerde ve bazen de vizyonda. Her sene yüzlerce film izlerim. Güncel sinemayı takip ediyorum. (Kadın/29 /Yüksek Lisans Öğrencisi/İstanbul)

Mümkün olduğunca vizyonda beğendiğim ve seçtiğim filmlere giderim. Sadece sinemaya gitmek için sinemaya gitmiyorum evde izliyorum. Evde haftada bir defa izliyorum. (Kadın/37 / Doktora 
Öğrencisi/İstanbul)

Her firsatta izlerim. İmkânım olsa her gün izlerim de firsatım olmuyor, haftada iki kere izliyorum. (Erkek/44 /Yüksek Lisans Öğrencisi/Gebze)

Seçtiğiniz filmlerde başarılı/bașarısız ayırdına nasıl varırsınız? Bir film sizin tavsiye listenize girmek için hangi özelliği tașımalı?

Filmden çıktığımda bir daha izleme hissi uyandıran, başkalarına önermem hissini uyandıran başarılı. Senaryo ve oyunculuğun iyi olması filmin tavsiye listeme girmesini sağlar. (Erkek/41/ Kütüphaneci/İzmir)

Çok keyif almadığımı düşündüğüm bazı filmlerde şöyle özellikler oluyordu çok olağanüstü şeyler normal hayatta yan yana gelmesi mümkün olmayan şeyler kurgu gereği filmde oluyor. Bu çok yapaylik katıyor. O yüzden gerçeklik diyorum ya. Bir film gerçeği ne kadar yansıtıyorsa o kadar mı başarılı sizin için? Evet, bir kahramanın ne olursa olsun ölmemesi bana çok yapay geliyor. Daha farklı olabilir daha hayata dokunan filmleri başarılı buluyorum. Yılmaz Güney Duvar filmi baya etkilemişti beni. Ilk olarak aklıma o geldi. O filmde doğrudan hayatın içinden alınan bir şey. Tavsiyelerim de bu yönde olur genelde. Edinilen gözlemlerin sahneye taşınmasl, gerçek hayatın yeniden üretilmesi. Hapishanede çekildiği için bir kısmı gerçek bile sayılabilir. (Erkek/29/Kütüphaneci/İstanbul)

İyi kurgu, uygun müzik, doğru oyuncu ve mekan seçimi, sinemasal tekniklerin yeterliliği. Tavsiye listeme girmek için özgün olmalı. (Erkek/55/Kütüphaneci/ Ankara)

Bir filmin benim için başarılı olup olmadığı ayırdına öncelikle çekimler ve oyuncu kalitesini baz alarak değerlendiririm. (Kadın/29/Kütüphaneci/İstanbul)

Iyi bir kurgu ile iyi oyunculuklar ve çekimlerle desteklenmiş ve bir ana fikri olan, bu fikrin mantıklı olup olmaması önemli değil, filmler benim için kıymetlidir. Kurgu, oyunculuk, yönetmenlik ve bir şeyler söyleyen bir derdi olanlar filmler. (Erkek/34/Kütüphaneci/Bilecik)

Konu ve derinlik önemli sanırım. (Erkek/43/Kütüphaneci/ İstanbul)

Merak uyandırıyorsa bir film başarılıdır. (Kadın/22/Lisans Öğrencisi/Bartın)

İlerken keyif alıyorsam, sıkılmadan izleyebiliyorsam o film başarılıdır benim için. Film sonunda "vay be" dedirtiyorsa tavsiye ederim. (Erkek/23/Lisans Öğrencisi/İstanbul)

Hikâye kurguysa, yönetmenin yarattı̆̆ karakterler ve olaylar dizisiyle vermek istediği duygu ve mesajları tam olarak verip veremediğine göre değerlendiririm genelde. Konu çok absürt olmadığı sürece filmdeki karakterlerin içine girebildiğimi hissediyorsam, film benim için başarllır. Eğer hikâye gerçek tarihsel olaylara dayanıyorsa, konunun ne kadar gerçeklere uygun şekilde ele alındığı da benim için bir kriterdir. (Erkek/27/Yüksek Lisans Öğrencisi/İstanbul)

Filmin senaryosu öncelikli olarak dikkatimi çeker, onu sıkılmadan izleyebilirsem benim için başarılıdır demektir. Tabii buna oyuncular da dahildir, severek izlediğim oyuncuların oynadığı filmler olduğu zaman severek izlerim. (Kadın/21/ Lisans Öğrencisi/İstanbul)

Mesela film süresi bir anda geçmişse bir anda geçmişse sıkılmamışsam filmden o film beni tatmin eder yani o film benim için iyi bir filmdir. Akıcı olması önemli, ilgime yönelik olması daha çok... Sıkılmadığım filmler benim için başarılıdır. (Erkek/25/Lisans Öğrencisi/Çanakkale)

Sürükleyici olmah demeyeceğim, sürükleyici olmasa da olur. Önemli olan başlangıcı ile finalinin birbirini tamamlaması ve senaryo yazarmın hakikaten de ne anlatmak istediğini bildiği konusunda 
kanaate varmam yeterli ola biliyor. (Erkek/21yaşında/Lisans Öğrencisi/İstanbul)

Anlatım olanaklarına bakarak hakkında okuduğum eleştirileri gözetirim genellikle. Beni heyecanlandırması bir filmi tavsiye etmem için yeterlidir. (Kadın/24/Lisans Öğrencisi/İstanbul)

Bir bütün aslında, oyunculuk da önemli, kullandıklar çekim teknikleri önemli konu önemli hepsini bir bütün olarak alıyorum. Çok film izleyince daha iyi eleştirmen oluyorsun. Kıyaslama şansın daha yüksek oluyor çünkü. (Kadın/29/Kütüphaneci/İstanbul)

Bence bir filmin başarısı, sinemanın tüm bileşenlerinin birbiriyle uyumuna bağhıdır. Şöyle ki bazen harika bir senaryonun çok kötü çekildiğine, ya da iyi senaryo-çekim içinde kötü oyunculuklara tanık olabiliyoruz. Filmi bitirdiğimde etkisi altındaysam ve izlerken sahi keyif almışsam, filmi tavsiye ederim. (Kadın/30/Yüksek Lisans Öğrencisi/İstanbul)

Beni etkilemeli ve inandırıcı olmalı. Oyunculuklar önemli ve senaryonun iyi işliyor oluşu. (Kadın/29/Yüksek Lisans Öğrencisi/İstanbul)

Baktığım zaman filme çok fazla tahmin edemiyor olmam lazım bir şeyleri. Yaratıcı olması lazım sonucunun ve aynı zamanda belirli söylediğim gibi zeki Demirkubuz'sa izlediğim ya da Nuri bilge ceylansa ondan beklediğim belirli kıstaslar var o ölçüde tavsiye ediyorum. Belirli çevredeki arkadaşlarıma tavsiye ediyorum zaten. Normalde ilk tanıştığım birine mutlaka izlemelisin kış uykusu dersen olmaz. 3 saat sıkılmayacak, üzerinde uzun uzun düşünecek ve aynı zamanda üzerinde konuşma yapabileceğimiz filmlerden hoşlanıp onları tavsiye ediyorum. (Kadın/37/Doktora Öğrencisi/İstanbul)

Sürükleyici olmalı. Filmden film bitene kadar sıkılmamalıyım. Heyecanlı bir şekilde izlemeliyim. Daha sonra izledikten sonra bende bir etki bırakmalı. (Erkek/44/Yüksek Lisans Öğrencisi/Gebze)

\section{Okuma alıșkanlığınız ne düzeyde?}

Düzenli okuduğum bir kitabım her zaman vardır. İlgimi çeken şeyleri okurum. Okumayı seviyorum. Edebiyattan beslenmek için edebî okumalar, yazı makale vb. için araştırma vb. çalışmalar okurum. (Erkek/41/Kütüphaneci/İzmir)

Okuma alışkanlığımın iyi olduğunu düşünüyorum. Son zamanlarda biraz düşse de, Türkiye gibi bir toplumda fazlası ile okuyan kişilerdenim herhalde. Ama eskiye göre düştü. Kitap okurken de yine tercihim sosyal konulara değinen ya da sosyolojik şeyler oluyor. Yine mesela filmde fantastik öğeli şeyleri sevmiyorsam kitapta da sevmiyorum. Düzenli olarak okurum ama. (Erkek/29/Kütüphaneci/ İstanbul)

Düzenli okuduğum bir kitabım her zaman vardır. (Erkek/55/Kütüphaneci/Ankara)

Okuma alışkanlı̆̆ımın yetersiz olduğunu düşünüyorum. İlgimi çeken şeyleri okurum. (Kadın/29/Kütüphaneci/İstanbul)

Düzenli okuduğum bir kitabım her zaman vardır. (Erkek/34/Kütüphaneci/Bilecik)

Düzenli okurum. (Erkek/43/Kütüphaneci/İstanbul)

Düzenli okuduğum bir kitabım her zaman vardır. (Kadın/22/Lisans Öğrencisi/Bartın)

Bu da film gibi, ilgimi çeken şeyleri okuyorum. İlgi alanıma göre seçiyorum kitapları da. (Erkek/25/Lisans Öğrencisi/Çanakkale)

Son dönemlerde çok sık okuduğum söylenemez, ama daima devam ettiğim bir kitabım vardır, ara sıra dönüp dönüp kaldığım yerden devam ederim. (Erkek/21/Lisans Öğrencisi/İstanbul) 
İlgimi çeken şeyleri okurum. (Kadın/24/Lisans Öğrencisi/İstanbul)

Kütüphaneciolduğumiçin elime kitap daha sık geçiyor. Özellikle Türkedebiyatında çalıştı̆̆ımdan dolayı eski kitapları okuyorum daha çok. Tarık Buğra olsun Yaşar kemal olsun Orhan kemal olsun edebî eserleri daha çok okuyorum. Güncel olan çok konuşulan kitapları da takip etmeye çalışıyorum. Ama son zamanlarda daha çok film izliyorum. Okuma şöyle teknik okumalar yapıyorum daha çok. Hobi olarak okuma yapamıyorum film izliyorum. (Kadın/29/Kütüphaneci/İstanbul)

İlgimi çeken şeyleri okurum. (Kadın/30/Yüksek Lisans Öğrencisi/İstanbul)

Kitap okumayı da severim. Mutlaka elimde bir kitap bulunur, bazen birkaç kitabı bir arada okuduğum da olur. (Kadın/29/Yüksek Lisans Öğrencisi/İstanbul)

Her gün mutlaka elimde bir kitap oluyor. Ya yolculukta ya serviste ya metroda vs. Her akşam mutlaka kitap okuyorum uyumadan önce. (Kadın/37/ Doktora Öğrencisi/İstanbul)

Her gün değilse bile iki üç günde bir mutlaka okurum. (Erkek/44/Yüksek Lisans Öğrencisi/ Gebze)

\section{Bir kitabı seçerken neye dikkat edersiniz?}

İlgi alanım, yazar ve konu önceliklidir. (Erkek/41/Kütüphaneci/İzmir)

Billboardlarda çok fazla yer alan kitaplarn tercih etmiyorum. Onların içinin boş olduğu aşikâr. Genellikle belli başlı yayınevlerinin kitapların kaliteli buluyorum ve onların çıkardığı araştırma sonuçların ele alan, düşünceyi ortaya koyan onu irdeleyen kitaplarn tercih ediyorum. Romanlara nazaran bu kitaplan tercih ediyorum. Romanlarda da yine aslında daha gerçekçi yapaylı̆̆ı sezdirmeyen hepsi kurgu ama okununca daha az yapaylı̆̆ı sezdiren. Yapaylı̆̆ı sezdirdiğinde keyif almıyorum. (Erkek/29/Kütüphaneci/İstanbul)

Yazarı, konusu ve ilgi alanlarm. (Erkek/55/Kütüphaneci/Ankara)

Kitabın konusuna göre seçerim. (Kadın/29/Kütüphaneci/İstanbul)

Kitabı konusuna göre seçerim. (Erkek/34/Kütüphaneci/Bilecik)

Konusu, ilgi alanlarım, ya da ilgi alanlarıma sızmasını bilmediğim meseleler. (Erkek/43/ Kütüphaneci/İstanbul)

Yazarına göre kitaplarımı seçerim. (Kadın/22/Lisans Öğrencisi/Bartın)

Yazarı ve ilgi alanıma göre seçerim kitabı. (Erkek/23/Lisans Öğrencisi/İstanbul)

Konuya ve yazara göre seçerim. Bir konu ilgi alanıma girmese de sadece öğrenmek için de o konuda kitap okurum. Bazen görüşlerini beğenmediğim (ideolojik açıdan) yazarların kitaplarını sadece karşıt görüşün savlarını öğrenmek için de okuduğum olur. (Erkek/27/Yüksek Lisans Öğrencisi/ İstanbul)

Kitabın yazarı, konusu. (Kadın/21/Lisans Öğrencisi/İstanbul)

Kitabın konusu önemli. Arkalarnndaki tanıtım yazısında özet şeklinde verilen kitapta ne anlattığına bakıyorum. Son dönemlerde yazara göre de okuyabiliyorum. Dan Brown, J. R. R. Tolkien mesela iyi de olsa kötü de olsa okuyorum. Konusuna bakmadan bazı yazarları iyi de olsa kötü de olsa okuyorum. (Erkek/25/Lisans Öğrencisi/Çanakkale)

Bir kitabı seçerken elbette ilk başta yazarına dikkat ediyorum. Yazarından pek emin olamazsam, 
"Okur kitabı arka kapaktan sevmeye başlar" teorisi uyguluyorum. Sevdiysem seçerim, sevmediysem seçmem. (Erkek/21/Lisans Öğrencisi/İstanbul)

İlgi alanlarım belirleyici oluyor (Kadın/24/Lisans Öğrencisi/İstanbul)

Biraz soyut düşünmeye çahş̧1yorum. Çok popüler olan kim var mesela günümüzde. Elif Şafak var mesela. Çok eleştiriliyor ama güzel bulduğum tarafları da var. Popüler diye kötü diyemeyiz her kitaba. Orhan Pamuk çok eleştiriliyor. Henüz okumadım ama okuduğum zaman hiç tanımadığım bir yazarın kitabı olarak bakacağım bu şekilde daha objektif algılayabilirim bazı şeyleri. Çok ayırmıyorum ben bunu açıkçası. (Kadın/29/Kütüphaneci/İstanbul) İstanbul)

Sanırım yazarına ve kendi beğenime dikkat ediyorum. (Kadın/30/Yüksek Lisans Öğrencisi/

Yazarı önemli. Daha önce okuyup sevdiğim bir yazarsa diğer kitaplarına da bakarm mutlaka. Klasikler herkes gibi benim de önceliğimdir. Edebiyatta güncele pek yönelmem. (Kadın/29/Yüksek Lisans Öğrencisi/İstanbul)

Öncelikle yazar, yönetmende olduğu gibi sonra da konusu. Sonra da yayınevi. Bazı çeviriler maalesef konusu ve yazarın bildiğim halde çeviri Metis ya da Can olmayınca çok zorluk çıkartabiliyor. (Kadın/37/Doktora Öğrencisi/İstanbul)

Verdiği mesaja. Sosyal konularla ilgili olmasına ve bilgilendirici olmasına bakarım. (Erkek/44 yaşında/Yüksek Lisans Öğrencisi/Gebze)

\section{Edebiyat ve Sinema Birlikteliğinde "Popülerlik" Sorunu: Uyarlama Filmlerin Bilinirliği Üzerine}

Görüşmecilerden alınan cevaplar bağlamında sinema ve edebiyat ilişkisi değerlendirildiğinde, görüşmecilerin çoğunun izledikleri uyarlama filmlerin kitap uyarlaması olduğunun farkında olmadıkları gözlemlenmiştir.

Sinema ve edebiyat birlikteliğinde sinemanın çağın koşullarına uygun olarak daha hızlı tüketim sağlaması, sinemayı edebiyatın önünde seyreder duruma getirmiştir. Sinemanın hız çağına uygunluğu göz önünde bulundurulduğunda, kitlenin izler kitle olarak güçlendiği, fakat okur olarak zayıfladığı bir dönemden bahsedilebilir. Çalışmanın ortaya çıkış sorusunu oluşturan "21. yüzyılda sinema edebiyatın hatırlatıcısı konumunda mı?" sorusu üzerinden ele alındığında, çalışmanın bu bölümünde yer alan sorular sinema ve edebiyat birlikteliğinin izler ve okur kitlenin zihinlerinde nasıl yer bulduğu yönünde değerlendirilebilir. Uyarlama filmlerin bir eserden uyarlama olup olmadığının bilincinde olunup olunmadığı yönünde bir farkındalık sorgulaması yapılmıştır. "İzleyici izlediği filmin edebiyat uyarlaması olup olmadığını biliyor mu? Biliyorsa eğer iki türü de karşılaştırma yaparak mı izliyor, yoksa her türü kendi içinde mi değerlendiriyor? Uyarlama filmler hakkında ne düşünüyor?". Çalışma bir saha çalışması olduğundan, bütün bu sorular edebiyat ve sinema birlikteliğinde görüşmecilerin deneyimlemeleri doğrultusunda cevaplanmıştır. Uyarlama filmler üzerinden yapılan değerlendirmelerde kitapların ve filmlerin görüşmecilerin gözünde nasıl yer edindiği de ortaya çıkmıştır. Bu nedenle görüşmecilerin farkındalık seviyeleri aslında okuma alışkanlıklarını da ele vermektedir. Uyarlama filmin eser üzerinden bilinirliği noktasında, görüşmecinin iyi bir okur olduğu da ortaya çıkmaktadır. Bu da okuma pratiklerinin değişimini gözlemlemek açısından önemlidir. Çünkü günümüz izler kitlesi, popüler kültürle de bağlantılı olarak, daha ziyade izlemek yönünde bir alışkanlık geliştirse de, söz konusu uyarlama filmler 
olduğunda, bilhassa farkında olduğu (daha önce okuduğu) bir kitabı sinemada gördüğünde memnuniyetsizlikle karşılamaktadır. Bunun sebebi edebiyatın sınırsız hayal dünyasından, filmin sınırlı hayal âlemine geçmesiyle bağlantılı olabilir. Bakıldığında görüşmecilerin bazıları da izledikleri filmlerin kitaplarını okuyunca beğenmediklerini beyan etmiştir. Burada sinemanın görsel anlatı gücünden bahsedilebilir.

Bütün bunların yanında sinemanın popülaritesi yadsınamaz bir şekilde arttığından, izleyici sinemada gördüğü uyarlama filmin kitabı ile karşılaştı̆̆ında "filmin kitabı çıkmış" yorumunda dahi bulanabilmektedir. Bu da okuma alışkanlıkları hızla düşerken, seyir kültürünün hızla yükseldiğini göstermektedir.

Okuduğunuz bir kitabı sinemada film olarak izlediniz mi? Karșılaștırma yapabilir $\underline{\text { misiniz? }}$

Yazar Kerim Korcan'ın Tatar Ramazan romanını okumuştum. Sonra Filmini izleniştim nette. Film kitabın önüne geçmişti. Oyunculuk performansı, müzikler metni aşmıştı. Sinema daha güzeldi ama bu her zaman böyle olmayabilir. (Erkek/41/Kütüphaneci/İzmir)

İzledim. Fahrenheit 451 bunlardan biri. Otomatik Portakal'ı da izlemiştim. Bazı insanlar filmi kitabın önüne koyar ben onlardan değilim kitabı filmin önüne koyarım aslolan benim için kitaptır. Uyarlamalar genelde bazen ticari kaygılarla bazen de yazılanlan filme aktarmak mümkün olmadığından olabilir her zaman bir değişikliğe uğruyor. Kitapta okuduğum birçok ayrıntı filmde yok veya filme eklenen kitapta yok. Birbirini tutmadığı çok açık. Benim için öyle. Dolayısı ile ben filmleri o kitapta olanı nasıl anlatmış olarak izliyorum. Filmin aslında benim için değeri kitabın arkasında kalıyor. Kitabın asıl olduğunu düşünüyorum, filmin onu ne yazık ki yer yer çarpıttığını sırf görsellik adına aslında aslı biraz bozduğunu bozabildiğini düşünüyorum. Aslinda hani bir prodüktör değilim belki de ya da yönetmen değilim gerekli bir şeydir yani elden gelmiyor olabilir ama kitabın aslın tahrip ettiğini düşünüyorum.

Her film için aynı șeyi düşünüyorsanız "çarpıttı̆̆ını" neden sinemaya gidip yine filmi görmek istiyorsunuz?

Kitapta yazanı bakalım yönetmen nasıl anlatmış aslında merak. Karşılaştırmak istiyorum. Birbirini tutmayacă̆ını varsayarak gidiyorum ama genelde öyle de oldu. (Erkek/29/Kütüphaneci/ İstanbul)

Evet-İnce Memed. Kesinlikle roman daha iyiydi. (Erkek/55/Kütüphaneci/Ankara)

Evet. Otomatik Portakal. Kitabı okurken daha fazla keyif almıştım. Filmde sahneler çok abartılmıştı. Kurgunun bu denli şişirilmesi kitabın düşünce gücünü öldürüyor. (Kadın/29/ Kütüphaneci/İstanbul)

Evet. Uçurtma avcısı. İkisinin de tadı ayrıydı aslında. Ama sinemanın görselliği iyi bir organizasyonla çok daha iyi anlatabilirken, kitaptaki yazar ve okuyucunun hayal gücünün sinırlarm belirginleştiriyor. Sinema da tek bir biçim var, izlediğimiz film. Kitapta ise yazarın anlatımından bizim hayal güсümüze kadar bir derya söz konusu. Yazar kelimeleri kullanır, stralar. Okuyucu da üzerine hayaller kurar ve tecrübelerinden bir dünya inşa eder. Sinema da bu yok. Senarist ve yönetmene esiriz. (Erkek/34/Kütüphaneci/Bilecik)

Evet. Blade Runner (Androidler Elektrikli Koyun Düşler mi?) Kitapta anlatılanlar daha zengin imgeler yaratıyor. Sinema teknikleri bunların hepsini kapsamayabilir, başka açılardan görme biçimlerimizi zenginleştirebilir. (Erkek/43/Kütüphaneci/İstanbul) 
Evet. Anayurt Oteli'ni örnek verebilirim. Kitapta Zebercet karakteri ve içinde bulunduğu ruh hali olağanüstü betimlenmişti, fakat sinemada izlediğim Zebercet karakteri sıradan bir karakterdi ve dolayısıyla film heyecan vermek bir yana oldukça vasattı. (Kadın/22/Lisans Öğrencisi/Bartın)

Stephen King- Kara Kule serisini okuyup izlemiştim. Kitapla alakası yoktu. 7 kitaplık seri tek filme indirilmişti ve berbattı. Hollywood klişesine çevrilmişti kitap. Genelde okuduğum kitaplarm filmini izlemem. (Erkek/27/Yüksek Lisans Öğrencisi/İstanbul)

Evet "Senden Önce Ben " kitabı. Kitap daha ayrıntıl, filmini izlediğim zaman hayal Kitap daha ayrıntılı, filmini izlediğim zaman hayal gücümün daha iyi olduğunu fark ettim. Kitapta tasvir pek yapılamamış gibi idi. (Kadın/21/ Lisans Öğrencisi/İstanbul)

Dan Brown Cehennem. Başarısız buldum filmi. Karşılaştırma yaptı̆̆ı̆mda kitap ve film arasında çok bağlantı yoktu. Filmde uyarlamışlar ama çok kesmişler, aynı içeriği yansıtamış daha yüzeysel kalmış.

Yüzüklerin Efendisi Yüzük kardeşliği ilk kitabın okudum, filmini de izledim. Ama bunda ilk filmi izledim sonra kitabı okudum. Kitapta içerik yoğun verilmiş film yüzeysel ama burada da cehenneme göre uyarlamayı çok başarılı buldum. Çok başarılı bir uyarlama olmuş.

Acaba bunda filmi önce izlemiș olmanın etkisi olabilir mi? Diğerinde cehennemi okumus ve ardından izlemeye gitmiștin kafandaki kurguyla gitmiștin izlemeye? Bu defa da izlediğin kurguyu kitapta bulamamıs olabilir misin?

Yüzüklerin efendisini çok sevdiğim için olabilir, ama iki filmde de uyarlama ve kitap birbirini tutmuyor. Mümkünatı yok, çünkü filmler genel olarak gişe başarı para kafasıyla yapıldığı için... (Erkek/25/Lisans Öğrencisi/Çanakkale)

Sinemada görmedim, ama okuduğum kitabın filmini evde izlediğim oldu. Liste uzun ama ilk aklıma gelen "Kitap hırsızı". Bence, kitabı daha etkileyici idi. (Erkek/21/Lisans Öğrencisi/İstanbul)

Koku'yu okumuştum aynı zamanda filmini izlemiştim. Çok eksik yönleri vardı. Atlamalar çok fazla vardı. Kitaba bağlıydı ama kitapta tasvir edilen kişi çok çirkin bir kişi olarak tasvir ediliyor fakat filmde gördüğüm adam başroldeki ismini hatırlamıyorum ama gayet hoş yakışıklı bir adamdı. Kitapta çok çirkin tasvir ediliyor. Filmde atlanan bunun gibi birçok yön vardi.

\section{Niye peki çirkin biri filmde yakıșıklı gösteriliyor?}

İlgi çekmek için olabilir mi? Seyircinin ilgisini daha çok çekmek için. Türklerden en basit örneği; Yaprak Dökümü. Zaten kitap incecik bir kitap çok değiştirmişler tamamen günümüze uyarlamışlar bambaşka bir eser ortaya çıkarmışlar. Bu diziydi gerçi ama ona rağmen baya eksikti. Genel olarak kitaplar daha iyi ama başarll filmler de var. (Kadın/29/Kütüphaneci/İstanbul)

Evet. Mesela Otomatik Portakal, Trendeki Kız, Ölü Ozanlar Derneği, Anayurt Oteli. Bunlar ilk aklıma gelenler. Ben sanırım film izlemeyi çok seviyorum ve çoğunda izlediğim filmleri hatırlıyorum. Mesela Otomatik Portakal zaten çok iyi bir eserdi ancak Stanley Kubrick çok çarpıcı uyarladı ve sanırım kitabın önüne geçti film hali, yani bence,. Ancak diğer yandan Anayurt Oteli'nde çok beğenilmesine rağmen ben, kitabını okurken filmini izlemekten çok daha fazla keyif almıştır. Sanırım bu duruma, yazara- yönetmene, bizim o anki halimize, kısacası her şeye göre değişiklik gösteriyor. (Kadın/30/ Yüksek Lisans Öğrencisi/İstanbul)

İlk aklıma gelen eskilerden aklıma Koku geldi. Kitabı çok ayrıntılı çok fazla konunun ayruntılarına yer veren bir kitaptı geniş anlamda hayal kurabiliyordunuz ama filminde belirli bir açıdan tabii zaman el verdiği açıdan bakılmış ve yüzde yüz yansıtmamıştı tam olarak. Ama 
yine de bu da teknik imkânlarla alakalı. Yani kitap çok iyidir film kötüdür demek istemiyorum, ama kitabın alt yapısında çok fazla seçenek çok fazla hayal dünyasına gönderme yapılabiliyor, ama filmde yönetmenin gözünden baktığımız için bazılan yine çok iyi bir şekilde canlandırılabiliyor. Ama bazı filmlerde kitabı yüzde yüz yansıtmadığını görüyoruz. Sonuçta teknikte var işin içinde ya da yönetmen belirli çerçeveden bakıyor onun da etkisi var. (Kadın/37/ Doktora Öğrencisi/İstanbul)

Oliver Twist kitabını okumuştum daha önce hikâyeyi kitaptan biliyordum sonra filmini izledim. Uyarlamayı başarılı buldum. Oldukça etkileyiciydi. Kitaptaki dönemi yansıtıyordu. Önem vermişlerdi. Filmin geçtiği zamanın ayrıntılarına önem verilmişti. Kitabı okurken de hayal dünyamda hemen hemen öyle canlanmıştı. (Erkek/44/Yüksek Lisans Öğrencisi/Gebze)

Bir filmi izledikten sonra onun daha önce yayımlanmıs bir kitap olduğunu öğrendiğiniz oldu mu? Yoksa her izlediğiniz filme bilinçli bir ssekilde mi gittiniz?

Hep bilinçli bir şekilde gittim. (Erkek/41/Kütüphaneci/İzmir)

Sinema salonuna film izlemeye çok fazla... Aslında şey fimi vardı galiba... Anna Karenina onun filmini izlemiştim fena film değildi ama kitabını okumadım. Bilinçli bir tercih olarak perdeye nasıl aktarıldığııı görmek için gidiyorum. (Erkek/29/Kütüphaneci/İstanbul)

Muhakkak olmuştur...(Erkek/55/Kütüphaneci/Ankara)

Çok fazla okuma alışkanliğım olmadı ̆̆ı için her filme bilinçli bir şekilde gitme olanağım olmuyor. Filmi izledikten sonra kitap uyarlaması olduğunu öğrendiğim çok oldu. Dediğim gibi okuma konusunda yetersiz buluyorum kendimi. (Kadın/29 yaşında/Kütüphaneci/Lisans Mezunu/İstanbul)

Genelde sinemada filmi izlemeden önce hakkında araştırma yaparım. Böyle bir durumla karşılaşmadım. (Erkek/34/Kütüphaneci/Bilecik)

Sinemada film seçerken araştırma şansımız daha yüksek ve film hakkında yayımlanan bilgilere bakarak seçim yapıyorum. Ama arkadaşların önerdiği filmleri bilgisayarda izledikten sonra araştırmada kitaptan uyarlandığına denk geliyorum. (Erkek/43/Kütüphaneci/İstanbul)

İzlediğim her filme bilinçli gittim. (Kadın/22/Lisans Öğrencisi/Bartın) İstanbul)

Bazen araştırırım ama gelişi güzel gittiğim zamanlar da oluyor. (Erkek/23/Lisans Öğrencisi/

Genelde gitmeden önce farkında olurum. Özellikle ünlü bir kitapsa. Ama farkında olmadiğım da çok film vardır. (Erkek/27/Yüksek Lisans Öğrencisi/İstanbul)

Gitmeden önce farkında olmak çok mümkün olmuyor. Genelde sinemadan sonra araştırınca farkına varıyorum ya da bir yerde görüyorum kitabı filmini izlemişsim diyebiliyorum... (Kadın/21/ Lisans Öğrencisi/İstanbul)

Dövüş Kulübü (Fıght Club) Çok şaşırmıştım bir kitabı olduğunu öğrenince" vay be "dedim. Da Vince Code'da öyleydi, ben onu yalnızca film sanıyordum... (Erkek/25/Lisans Öğrencisi/ Çanakkale)

Olmadı da, ama böyle bir olay gerçekleşti. Zeki Demirkubuz'un "Yazgı" filmini izlediğimde film boyunca bazı şeyler tanıdık gelmişti ama çıkaramamıştım, film bittikden sonra Camus'ün "Yabancı" romanından uyarlama olduğunu öğrenmiştim. (Erkek/21/Lisans Öğrencisi/İstanbul) 
Hiç dikkat etmedim. Bu durumda öncesinde haberdar olmadan gittiğim filmler olmuştur. Filmi izledikten sonra kitap uyarlaması olduğunu öğrendiğim... (Kadın/24/Lisans Öğrencisi/İstanbul)

Mutlaka olmuştur. Takip edemiyorum ama sonradan duyuyorum kitabı da varmış diye. Önce filmi izleyip ondan sonra haberdar oluyorlar kitabından. (Kadın/29/Kütüphaneci/İstanbul)

Sonradan öğrendiğim elbet oldu. Hatta bazen çok ünlü filmlerin esasen çok bilinmeyen kitaplardan uyarlama olduğunu öğrenebiliyoruz. (Kadın/30/Yüksek Lisans Öğrencisi/İstanbul) İstanbul)

Filmleri izlemeden önce genellikle bilgi sahibi olurum. (Kadın/29/Yüksek Lisans Öğrencisi/

Hep kitabını okuduğumun filmine gittim bilinçli şekilde. (Kadın/37/Doktora Öğrencisi/ İstanbul)

Ben bazen özellikle kitaptan uyarlanan filmleri arar öyle gider izlerim. Çünkü kitaptan uyarlama filmler daha izlemeye değer benim için. Buna özellikle dikkatederim. Internetten arama yaparım. Kitaptan ve edebiyattan uyarlama filmler diye. Öyle bilinçli şekilde izlerim. Edebiyata öncelik veriyorum ve bu tür filmler hikaye bakımından daha sağlam oluyor. Kitap yazllırken üzerine düşünülmüş olduğundan kurgu daha sağlam oluyor. Diğer filmlerde kurgu hayal kırıklı̆̆ yaşatabiliyor ama să̆lam edebiyat eserlerinde ben böyle bir şeye rastlamadım. (Erkek/44/Yüksek Lisans Öğrencisi/Gebze)

Edebiyattan uyarlanan filmler hakkında ne düşünüyorsunuz? Sinema ve edebiyat ilişkisini günümüz penceresinden değerlendirir misiniz?

Edebiyattan uyarlanan filmler genelde başarılı buluyorum. Çoğu zaman metinden uzaklaşsalar da görselin gücü metnin önüne geçiyor. Bazen metinde güç, tat görsele aktarllamıyor. Herkesin kendi zihninde oluşan kahraman, sokaklar, zaman sinemada öznelliğini yitiriyor. Tek başına yapılan okuma bireyleri daha etkilemesi çok normal. Her okuma ayn bir sinema filmi çekimi gibi düşünün. Edebiyatın sinemaya uyarlamaları asıl metine okurda uyandırdığı hisse sadık kalmalı. Ama günceli yakalama ve gişe derdi genelde filmlerin metinden ayrilmasına ve popülerliğe itiyor. (Erkek/41/Kütüphaneci/ İzmir)

Yeni bir şeyler üretmektense var olan bir şeyi beyaz perdeye aktarmak, kolaycllık demeyim de yeni bir malzeme üretmektense var olanı kullanmak belki işlerine geliyor olabilir. Bunu yaparken kitabın verdiği tadı bozdukların düşünüyorum. Görselliğe daha fazla önem veren kişi için bu keyifli olabilir ama benim için değil. Merak edilebilir, kitapta yazanların gerçek hayatta nasıl olacağına dair film belki bir şeyler söyleyebilir ama bana söylerken bozduğunu düşündürüyor. Tasvip etmiyorum diyemem öyle bir hakkım yok.

Peki söyle bir değerlendirirsek; günümüzde okuma alışkanlığının çok düşük olduğunu biliyorsunuz. Bu açdan edebiyatın hatırlatıcısı konumunda bir sinema, mesela orada gidip filmleri izleyip böyle bir kitap varmıs diye o kitabı almaya tesvik ediyor mudur sinema sizce? Yoksa orada izleyip de daha sonra iște bunun kitabını okumaya yine aynı șekilde gerek duymuyor mudur sinema izleyicisi?

Galiba sırf filmden sonra kitabını okumak isteyenler oluyor. Bir merak uyandırıor herhalde. Filmi görüp de kitabı nasıl olabilir diye. Biraz duyuyorum çünkü. O filme ait kitaplar daha popüler olmaya başlıyor reklamları daha fazla yapılıyor. Demek ki insanlar ona yönelebiliyor. Kötü bir şey değil herhalde insanlarn okuması neden kötü olsun ama gönül isterdi ki o filme gerek kalmadan da insanlar zaten okuyor olsaydı ama film bu konuda yardımcı oluyorsa da kötü bir şey değil bu. 


\section{Siz yardımcı olduğunu düșünüyor musunuz?}

Kitabın filminin yapılması reklamının yapılmasını sağlıyor. Bir şeyin reklamı yapılıyorsa da büyük ihtimalle satılıyordur günümüzde malum katkısı oluyor galiba...

\section{Sinema edebiyatın besleyicisi mi?}

Yazılmış bir hikâye ya da romanın dizi ya da film formatında perdeye aktarıldığı çok örnek var ama tersi var mı o kadar bilmiyorum. Varsa bile çok az herhalde. Böyle bir moda mod sonuca varmaya çalışırsak demek ki edebiyat sinemaya bir malzeme sağlıyor. Ama sinema kitaba malzeme sağlamak konusunda pek şey değil herhalde. Kitabın reklamını yapıyor sayılabilir. Edebiyatın eserinin belki de uyuyan insanların hiç haberi olmayan edebiyat eserinin günümüze çıkmasını tekrar să̆lıyor ama tersi yok. (Erkek/29/Kütüphaneci/ İstanbul)

Edebî eserin sinemaya uyarlanması edebiyatın tanıtımı için değerli bir katkı olmakla beraber edebî bir değer taşımamakta olup, başanlı bir senaryo, karakterlerin iyi canlandırılması, doğru mekân seçimi ve sinematik tekniklerin iyi uygulanması ile kurgulanmış ise sinemasal öneme sahiptir, sanat eseridir. (Erkek/55/Kütüphaneci/Ankara)

Edebî eseri sinemaya birebir aktarmak mümkün değil. Süre kısıtı, gişe kaygısı gibi nedenlerle edebî eser çok da başka bir yönde kurgulanabiliyor. Bu tamamen yönetmenin isteğine kalmış bir durum. (Kadın/29/Kütüphaneci/İstanbul)

Edebiyat sinema ilişkisi şahsi kanaatim karşılıkl etkileşimle devam eden bir süreçler bütünü. Yazanlar izlediklerinden, izlenecek bir şeyler çekmek isteyenler de okuduklarnndan etkileniyor. Okuyan ve izleyenler de nimetleniyor. Sinema, edebiyata görece daha pahalı ve masrafl bir uğraşı. Edebiyatı tek başınıza okunma sayısına bakmaksinız yapabilirsiniz. Sinema da bu biraz zor. Ekipman, kostüm, oyuncu, teknik detaylar, mekânlar gibi bir sürü pahalı şey var. O yüzden de sponsor gerekir, tekrar üretebilmek için izlenmesi gerekir. Reklamını yapabilmeniz için para ve çevre gerekir. Edebiyat ise çok öyle sayılmaz. Edebiyatın bir diğer avantajı da farklı kişiler için tekrar edilebilir olmasıdır. Her filmin bir izlenme dönemi vardır. Çok çok az filmin, sinema salonlarından sonra izlenme talebi salonlar kadar olur. Maliyeti de yüksek olduğu için genelde tekrardan salonlarda izlenmez. DVD olarak satılır. $O$ da pek Türk insanına göre değildir. Kitap ise tam olarak öyle sayılmaz. 500 adet basarsinız piyasa da biter yine basarsınız. Bu sonsuza kadar devam edebilir. Ve bazı dönemlerde ilk çıktığından daha fazla da satılabilir. Buna en iyi örneklerden ikisi Kürk Mantolu Madonna ile Tutunamayanlar'ı vermek mümkündür. (Erkek/34/Kütüphaneci/ Bilecik)

Edebiyattan uyarlanan çok başarılı filmler izleyebiliyoruz. Ne de olsa kökeni edebiyata, metine dayanan bir sanat dalı sinema. Sinemanın anlatma imkânlarn fevkalade iyi. Düşünme ve bunu ifade edebilme şekli açısından her iki dalın çok kuvvetli yanları var ve birbirlerini besledikleri kaynaklar neredeyse sinırsız. Sinemacı iyi bir okurdur, edebiyata göbekten bağhıdır. (Erkek/43/Kütüphaneci/ İstanbul)

Edebiyattan beyaz perdeye alman her metinde, metin orijinal halini kaybederek şekil değiştirmektedir. Bu sebeple uyarlama filmlerin kitaplarm, filmlerinden daha başarll buluyorum. (Kadın/22/Lisans Öğrencisi/Bartın)

Günümüz sinema anlayışı toplumsal olaylar hakkında eleştiri niteliğinden uzaklaşmış ve edebiyattan faydalanamıyor. Edebiyat anlatmaya bağh bir sanat dalıdır ve sinemanın bundan faydalanması gerekiyor ama günümüzde bundan uzaklaşıldl. Acaba en son hangi roman sinema salonlarında yer buldu? (Erkek/23/Lisans Öğrencisi/İstanbul) 
Kitapları okuyunca film uyarlamaları genelde yavan gelir bana. İyi örnekleri de var kuşkusuz ama genelde (özellikle fantastik olanlarn) film versiyonlarn Hollywood klişelerinden nasibini ahyor. Filmlerin kitaplardan çok daha fazla tüketildiğini ve dolayısıyla ticari değerinin çok daha fazla olduğunu düşünüyorum. Bu durum klişe film sektörünü karlı bir sektör yapıyor. Özellikle fantastik kitaplardaki derinliğin filmlerde es geçildiğini, efektlerin ve klişe diyalog ve eylemlerin dozajının arttırılarak seyircinin sıkılmamasının ve dolayısıyla filmin satmasının amaçlandığııı düşünüyorum. (Erkek/27/Yüksek Lisans Öğrencisi/İstanbul)

Bence edebiyat eserini okurken yaşadığımız haz, mevcut değil sinemada. Sinema daha fazla gişe kaygısı güttügüüden dolayı, eseri sinemaya aktarırken daha günümüz imajı ile veriyor. Bu defa o ana bambaşka bir bakış açısı getirebiliyor. (Kadın/21/ Lisans Öğrencisi/İstanbul)

Film yaparken kaygılar oluyor insanlar neyi beğenir neyi beğenmez ona göre film yapıyorlar. Hasılat gişe dedikleri o yüzden uyarlarken başarısız gibi görüyorum genel olarak. Başarılı olan çok az film var çeviri.

Sinema aslında edebiyatın hatırlatıcısı konumunda. Ne düşünüyorsun?

Görsel hafiza daha kalıcı. İzlenen film kitaptan daha iyi hatırlanıyor. Filmler içerik ne kadar değiştirilse de edebiyattan haberdar olunması konusunda iyi bir hatırlatıcı olabilir.

\section{Sinema açısından bakacak olursak, kurgu yaratmak yerine hazır kurguyu kullanmak?}

Hem yazarın ismini hem kitabın popülaritesini kullanıyor. Yeni şarkılarda da mesela cover yapıyor eski şarkıya sunuyor önüne yeni bir şeymiş gibi. Üretmiyorlar. Özgün içerik yok. Her şey bir öncekinin aynısı ya da biraz değiştirilmiş hali. Senaristlerde aynı şeyi yapıyor, telif hakkını ödüyor ve sonrasında biraz değiş̧tirerek tüketiciye sunuyor. (Erkek/25/Lisans Öğrencisi/Çanakkale)

Genelde kitaplar daha etkili kalıyorlar, ama edebiyatın sinemaya uyarlanmasının kesinlikle iyi bir şey olduğu kanaatindeyim. Böylece, kitaba merakı olmayan birçok kişi o kitabın filmini izleyerek bir şeyler almış oluyor, kendisi de bilmeden bir kitap okumuş oluyor. Diğer yönden de yazarlar açısından da muazzam bir şey. Bir yazarın en mutlu olacă̆ı şey kă̆ıda döktü̈̆̈̈ olaylarm birileri tarafindan canlandırılması olur herhalde. (Erkek/21/Lisans Öğrencisi/İstanbul)

Genellikle kurgu kitaplar gibi olmuyor. Sinema perdesine benim hayal gücüm yansımamış olduğundan aradığımı bulamıyorum diyebilirim. (Kadın/24/Lisans Öğrencisi/İstanbul)

Okumayan bir millet olduğumuz için hala oradaki hikâyeleri senaryoları film aracılığı ile de olsa insanlar bilmiş oluyor, görmüş oluyor çok önemli eserleri. O yüzden faydalı buluyorum ama kitabın tadı da başka tabii. Kitapta bir hayal gücün var. Senin belirlediğin senin çizdiğin figürler var. Filmde önüne seriliyor. Yani hayal gücünü geniş tutmak açısından daha çok keyif verebilir kitap okumak. Filmler kitabın yerini alamaz ama yapılmaya devam edilmeli.

\section{Okuma oranlarına faydası olduğunu düșünüyor musunuz?}

Tabii ki sırf merak için bu popüler dediğimiz filmleri bile okuma alışkanliğı edindirme açısından faydalı buluyorum. Çünkü insanlar sırf meraktan okuyor. En son ne vardı? Fi vardı galiba. İnsanlar dizisini izlediler ben de izledim sonra hepsi kitabın okumaya yeltendi yöneldi. O kitapla başlar okuma alı̧̧kanlığı edinir izleyici böylelikle ne olur bir alı̧̧kanlı̆̆ı devam ettirebilir. (Kadın/29/Kütüphaneci/ İstanbul)

Sinema ve edebiyat ilişkisini seviyorum, doğrudan olan ilişki dışında uyarlamalar hoşuma 
gidiyor, ancak mesela film afişinin kitabın kapağına basılmasından hiç hoşlanmıyorum, zira bu bence oldukça saygisizlik edebî esere ve hatta bence genel anlamda edebiyat ve sinemaya. Şu siralar bu okuma alışkanlığını arttırıcı bir unsur olarak görünebilir ancak ben ne olursa olsun okunsun anlayışına karşıyım ya da ne olursa olsun izlensin anlayışına... Edebiyatın da sinemanın da özerk alanları var ve üretim alanları olarak varlar. Sinema ve edebiyat ilişkisi piyasalaşmamalı aksine kaliteli işlerin ortaya çıkmasına vesile olmalı bence. (Kadın/30/Yüksek Lisans Öğrencisi/İstanbul)

Edebiyat uyarlaması oldukça zor. Yazılı dilin verdiğini sinemanın aynı görsellikle verebilmesi imkânsıza yakın bana göre. Ama mutlaka olmalı. (Kadın/29/Yüksek Lisans Öğrencisi/İstanbul)

Yine benzer şeyleri söyleyeceğim ama her zaman kitap okumayı tercih ederim. Kitapta daha fazla detay var. Kitaptakilerin birebir yansımaların filmde göremiyor olamayabiliriz ama filmde de iyi çekilmişse konunun özüne iyi bir şekilde hedef alınmış ve varılmak isteniyorsa onu görsel olarak da izlemek keyifli oluyor. Ama popüler kaygılardan ötürü gişe kaygılarından ötürü çok fazla derine inme kısmı yapılmadan sadece görsellikle ünlü oyuncularla canlandirllarak popüler kültüre hizmet ettiğgini düşünüyorum. Ama normalde faydalı çünkü edebiyat kitabını okumamış biri filmi görüp daha sonra da onun kitabını derinlemesine okumasına da imkân sağlayabilir. Sinemayı çok sevdi filmi çok sevdi. "Aa ben kitabını da okuyayım" dedirtebilir. (Kadın/37/Doktora Öğrencisi/İstanbul)

Öncelikle edebiyat uyarlamaların başarılı buluyorum. Sinema kalitesi açısından, kurgu ve hikâye örgüsü çok başanlı oluyor. Özellikle edebiyattan uyarlanan sinemalan izlerim. Onlarn listesini tutar takip ederim. Yalnız şuna dikkat ediyorum, eski zamanlarda yazılmış hikâyeler daha güzel, daha sağlam oluyor ilgimi çekiyor daha sürükleyici oluyor. Özellikle 17. Yy ve 20. Yy kitapları. Yalnız son on beş yirmi yılda yazılmış olan kitaplarda bunu göremiyorum. Bunun da sebebi sosyal sorunlan ele almayışı. Günümüz kitaplarn daha çok böyle bireyin kendi iç dünyasındaki durumunu ele alıyor, bir insanın penceresinden bakıyor. Ama bahsettiğim benim hoşuma giden edebiyat konularında ise sosyal konular, toplumsal sorunlar daha ă̆ırlıklı olduğu için daha çok hoşuma gidiyor. Günümüz kitaplarında daha soyut konular işlendiği için nostaljik takılıyorum. Harry Potter ile Gazap Üzümleri arasında çok çok fark var mesela. O zamanki insanlar daha derinlikli, daha düşünceli, daha nitelikli idi. Bu filmleri defalarca izleyebilirim ama bir Harry Potter'ı ikinci kez izleyemem. (Erkek/44/Yüksek Lisans Öğrencisi/Gebze)

\section{Sonuç}

Edebiyat ve sinema ilişkisi bağlamında izler ve okur kitle görüşleri doğrultusunda değerlendirildiğinde, görüşmecilerden alınan cevaplar uyarlama filmlerin bilinirlik düzeylerinin düşük olduğunu göstermektedir. 21. yüzyılda hız çağına uygun olarak sinemanın hızlı tüketime neredeyse en uygun araç olması, sinemayı diğer anlatı araçlarından daha avantajı bir konuma taşımaktadır. Sinemanın görsel anlatı metodu, uyarlama filmlerde edebiyat anlatısından faydalansa da edebiyat eserini kendi perspektifinde biçimlendirdiği ve yorumladığından dolayı edebiyat eserinin özgünlüğünden çok, sinemasal yönteme önem vermektedir.

Bir edebiyat eserini okumakla kıyaslandığında, sinemanın görsel şöleni daha kısa sürede ve daha keyifli zamanlar vadettiğinden, günümüz bireyi okumak yerine izlemeyi tercih etmektedir. Burada söz konusu olan durum, çağın koşuları doğrultusunda bir tercih olarak değerlendirilebilir. Kapitalizm ile birlikte tüketmek olgusu hayatın hemen hemen her alanını işgal ederken, buna bireyin boş zamanları da dâhil oldu. Sinema bu açıdan ele 
alındığında, bireye daha kısa sürede daha fazla tüketim imkânı tanıdığından, daha cazip hale geldi. Bakıldı̆̆ında bireyin iki saatte okuması çok da mümkün olmayan edebî eserleri sinema iki en fazla üç saat gibi bir zaman aralığında bireye sunmaktadır. Bu da edebî eserin yanında sinemanın popülaritesinin bu denli artmasını açıklamaktadır. Hatta günümüz edebî eserlerine bakıldığında da "dizi kitap" dediğimiz daha az sayfalı, daha akıcı, daha yüzeysel ve belki görsellerle de desteklenmiş, edebî yazından uzak kitaplar çok satanlar listelerinde arzı endam etmektedir. Böyle bir durumda sinemanın popüler kültür ile dirsek teması halinde olması, daha çok tercih edilmesini de açıklamaktadır.

Sinema ve edebiyat arasındaki karşılıklı etkileşim durumu, sinemanın var olmaya başladığı dönemden beri edebiyatın sinemayı konu bakımından destekleyen bir alan olduğu yönünde tanımlanabilir. Fakat bugüne geldiğinde sinema, başka bir açından bakıldığında, edebiyatı görünür kılan, gündeme taşıyan veya popülerliğini arttıran bir alan olarak da değerlendirilebilir. Oysa yapılan görüşmelerde görüşmecilerin çoğu uyarlama filmlerin ardındaki eserden haberdar değil. Filmi izledikten sonra kitap uyarlaması olduğunu öğrenirlerse de şaşırdıklarını, hatta sinema ile özdeşleştirdikleri Fight Club (Dövüş Kulübü, David Fincher, 1999) gibi birçok filmi kitap olarak hiç akıllarına getirmediklerini belirtmekteler. Aslında bu durum, çok tartışılan "sinemanın edebiyat eserini perdeye taşırken eserin özgünlüğünü gözetip gözetmediği” sorusunun günümüzde geçerliliğini yitirdiğine işaret ediyor da denebilir. Çünkü uyarlama filme konu olan eseri daha önce okumamış olan izleyici, eserin varlığından haberdar değilken, sinemada izlediği filmi eserle mukayese ederek değerlendirme durumu söz konusu olmadığından, eser o an en azından izleyici için salt bir film olarak iyi veya kötü olarak değerlendirilmektedir. Burada söz konusu değerlendirme eserin başarılı bir uyarlama olup olmadığı değil, o an izlendiği kadarıyla seçilen oyuncular, mekân, ses ve 1şık eleştirisinden öteye gidememektedir. Görüşmelerde ortaya çıkan edebî eserden uyarlama bir film izlediğini bilmeyen izleyici için, uyarlama film değerlendirmesi yapmak, salt film değerlendirmesi yapmakla özdeş bir durumdur. Kıyaslama yapacağı bir durum söz konusu olmadığından yalnızca film üzerinden bir değerlendirme yapmaktadır. İzlenen filmin başarılı bir film olduğu yönünde kanaat geliştirmelerine yardımcı olan genel kanı "sıkılmadan izleme" yönünde olmaktadır. İzler kitlenin çoğu, izlediği filmin sıkmadan, hızlı bir şekilde zaman geçirtmesi yönünde bir iyi film algısına sahip olmanın yanında çoğu da ilgi alanlarına yakın alanlarda izlemeler yapmaktadır. Şöyle ki, bilişim alanında okuyan veya sayısal mesleklere vakıf öğrencilerin daha ziyade fantastik, bilim kurgu dediğimiz alanlarda izlemeler yaptıkları gözlenmiştir.

Okuma pratikleri açısından değerlendirildiğinde, bireyin okuma alışkanlıklarının yerini izleme alışkanlıklarına bıraktığı görülmektedir. Görüşmecilerin hemen hemen hepsi düzenli okudukları bir kitapları olduğunu söylese de, her akşam bir film veya haftada bir film izlemek yönünde beyanları ile kıyaslandığında, daha çok izler kitle olmayı tercih ettikleri görülmektedir. Bütün bu görüşmeler sonucunda bireyin uyarlama filmler üzerinden değerlendirilen okuma ve izleme alışkanlıkları ve farkındalıkları, izleme yönünde artan bir popülerlik ve okuma yönünde de gözle görülür bir düşüş olduğunu göstermektedir. Uyarlama filmin beslendiği edebiyat eseri, sinemanın ilk ortaya çıkışından bu yana olduğu gibi günümüzde de konu bakımından sinemayı beslemeye devam ederken, sinemanın bu ilişkide yeni işlevi kuşkusuz eserin bilinirliğini arttırmak yönünde olmaktadır. Ne var ki sinemanın yadsınamaz etkisine rağmen, çoğu görüşmeci izlediği filmin uyarlama bir film olduğundan habersiz, iyi bir film olduğu yönünde değerlendirdiği filmleri salt sinema eseri 
olarak bellediğinden dolayı, çokça tabir edilen "filmin kitabı çıkmış" ironisi gerçekleşmektedir. Burada söylenmeye çalışılan, edebiyatın sinema karşısında değer kaybettiği değildir. Yalnızca sinemanın, diğer anlatı çeşitlerinden daha fazla tercih edilmesinin görüşler doğrultusunda bir değerlendirmesi yapılmaktadır. Bu doğrultuda değerlendirildiğinde izler ve okur olarak görüşlerine başvurulan görüşmecilerin söylemleri esas alınarak oluşturulan bu çalışmada, günümüz edebiyatının sinemanın gölgesinde seyrettiği gözlenmiştir.

Özetle, sinemanın bu çağa en uygun araç olması, filmlerin tercih edilmesinde temel sebep olarak gösterilebilir.

\section{Kaynakça}

Akbayır, S. (2014). Edebiyat ve Disiplinlerarası Etkileşim. Ankara: Pegem Akademi

Atar, S. (2005). Edebiyattan Sinemaya: Frankenstein. İçinde Y. Okur (Ed.), Sinefil 2004 (Toplu Basım) (ss. 260-261). İstanbul: Boğaziçi Üniversitesi Mithat Alam Film Merkezi.

Baydur, M. (2004). Sinema Yazıları. İstanbul: İletişim Yayınları.

Cartmell, D. (2012). 100+ Years of Adaptations, or, Adaptation as the Art Form of Democracy. Içinde D. Cartmell (Ed.), A Companion to Literature, Film, and Adaptation (ss. 1-13). West Essex: Blackwell Publishing.

Currie G. (1995). Image and Mind: Film, Philosophy, and Cognitive Science. Cambridge: Cambridge University Press.

Dmytryk E. ve Dmytryk P. (2007). Sinemada Yönetmenlik, Oyunculuk, Kurgu. (Ş. İbrahim, Çev.) (2.bs). İstanbul: Doruk Yayımcılık.

Ertürk,İ. (2008). Perde'li Düşünceler: Yönetmenler ve İzlekler Işığında Sinema. İstanbul: Yapı Kredi Yayınları.

Esslin, M. (2001). Televizyon Çağı: T. V. Beyaz Camın Arkası. (M. Çiftkaya, Çev.) (3. bs). Ankara: Pinar Yayınları.

Kale, Ö. (2010). Edebiyat ve Sinema İlişkisi. Uluslararası Sosyal Araştırmalar Dergisi, 3 (14), ss. 266-275.

Kayaoğlu, E. (2016). Edebiyat ve Film Edebiyat Bilimi Yaklaşımıyla Film Çözümlemesine Giriş. İstanbul: Hiperlink Yayınları.

Kemp, P. (2014). Sinemanın Tüm Öyküsü.(E. Yılmaz ve N. Yılmaz, Çev.). İstanbul: Hayalperest Yayınları.

Kırel, Y. (2014). Uyarlamak mı? Uyumlanmak mı? : "Tersyüz-Adaptation”. Galatasaray Üniversitesi İletişim Dergisi, 1(1), ss. 115-134.

McFarlane, B. (1996). Novel to Film: An Introduction to the Theory of Adaptation. Oxford: Clarendon Press. Yayınları.

Stam, R. (2014). Sinema Teorisine Giriş. (S. Salman ve Ç. Asatekin, Çev.). İstanbul: Ayrıntı

Uğurlu, F. (1992). Edebiyat ve Sinema, Kurgu Dergisi, 11, ss. 135-151. 
Ünal, Y. (2015). Dram Sanatı ve Sinema Klasik Anlatı Yapısının Kökenleri. İstanbul: Hayalperest Yayınlar1.

Özön, N. (2008). Sinema Sanatına Giriş. İstanbul: Agora Kitaplığı.

Teksoy, R. (2005). Rekin Teksoy'un Sinema Tarihi. İstanbul: Oğlak Yayıncılık.

Yüce, T. (2005). Sinema ve Edebiyat Türleri Arasında Görülen Etkileşimler. Zonguldak Karaelmas Üniversitesi Sosyal Bilimler Dergisi, 1(2), ss. 67-74. 